\title{
Institutional Synergism as the Information Center for Agriculture Development in Indonesia
}

\author{
Muhammad Alif $^{1 *}$, Selly Oktarina, ${ }^{2}$, Anna Gustina Zainal ${ }^{3}$ \\ ${ }^{1}$ Study Program of Communication Sciences, Universitas Lambung Mangkurat. \\ ${ }^{2}$ Study Program of Agribusiness, Faculty of Agriculture Universitas Sriwijaya \\ ${ }^{3}$ Study Program of Communication Sciences, FISIP Universitas Lampung \\ Correspondent Email: muhammad_alif@ulm.ac.id
}

Received: March 10, 2021 Accepted: September 15, 2021 Online Published: October 28, 2021

\begin{abstract}
Ignorance and lack of information related to development development to achieve prosperity in rural areas makes it very important the role of institutions in bridging as the information center. Institutional empowerment will push the improvement of farmer productivity which can affect the well-being of farmer life. The purpose of this article is to determine the role of institutions in the development of the Center for Agricultural Development Information in rural and the efforts that can be made to create synergy between institutions and PIPP. This paper uses a literature review by looking for relevant references according to existing problems. The data has been obtained are then analyzed using descriptive analysis methods. The results and discussion show that shows the very important role of institutions in carrying out their duties and must synergize between institutions with one another. The kinds of the institutional are Universities, Local Governments, Opinion Leaders, Non-Governmental Organizations, Agricultural Extension Officers, Farmers Contacts, Gapoktan, Farmers Groups, Other Institutions. The role of institutions is to establish cooperation, disseminate research results, convey information, create demonstration plots as pilots, provide motivation and develop farmer capacity. Empowering farmers through common perceptions and alignment of goals, strengthening institutions for the continuity and sustainability of resources and structuring institutional capacity, improving institutional management, improving leadership patterns, and transparency.
\end{abstract}

Keywords: Agricultural, communication, development, information, rural.

\section{Introduction}

The low access and lack of institutional role to the information of agriculture development affect the limitation of farmer's knowledge. These things affect the information discrepancy of agriculture development; therefore, it needs to cover up these problems. It can be done by the dissemination of information on agriculture development. The growth in rural is an excellent process to change all of the aspects for the people, such as the economy, social, political, culture, religion, defense, and security. These aspects can make the rural people better and gain an optimistic target of life (Touihri, M., et al. 2019). However, along these times, agriculture development in rural is still slow, especially for the access of innovation information, marketing, and result production. These are caused by ignorance, and the lack of interest in search information can also be caused by less information related to agriculture development (Muñoz-Pascual, L., \& Galende, J. 2020)

Farmers' behavior is the leading cause of the lack of information. They tend to wait for the new data from the instructor. It makes them become passive and cannot get many pieces of information. There is a tendency of the farmer to wait for the data from the instructor by attending the group meeting (Andriaty, E., et al.2011). Besides, lack of interest in searching for information that relates to the easiness of media communication access. Generally, farmers are getting used to the original technology in rural that the development in this place 
develops slowly and needs more time to be increased (Anderies, J. M., \& Janssen, M. A. 2013). The resistance to new technology could be more significant if the farmers cannot understand, prove, and practice the development themselves. Understanding development for farmers means actual proof without knowing the process, cause, and effect or the relation with other factors (Alif, M. 2017).

These things relate to the people's mindset to be better and able to build the resource. It indirectly makes them want to get more information about human resources (SDM) and natural resources (SDA). Communication has a vital role to the mindset equalization, mindset creation, and mindset implementation on the agriculture institutional includes in the form of bonding, bridging, and linking so that there will be a synergy both inside and outside the institutional. (Oktarina, S., \& Rustiadi. 2008). Local government agencies can explore the possibility of assisting micro-business in gathering information for periodic evaluations and alerts the financial status of micro-enterprises for reporting purposes, including rural development information (Quingco Joyfe G, \& S, L. C. 2019).

Due to the lack of information access faced by rural, people there must be an Information Center of Agriculture Development (PIPP). This is caused by some actors who have the motivation to develop agricultural areas in rural. They are the ones who will change the agriculture situation to be better (Zainal, A. U., \& Prakoso, G. H. .2019). with the other farmers to build their agriculture. Information Center of Agriculture Development defines as a place or link that provides some information among some parts that have an interest in agriculture development. The Information Center for Agriculture Development is accumulating all of the information, such as teaching, entertaining, or influencing. The difference between executing costs and key leaders is that their participation and implementation reflect their interactions (Lorayna, K. J. A., \& Caelian, M. V. 2020).

Information dissemination from the Information Center of Agriculture Development (PIPP) can be done by using communication media such as printed and electronic media. But some challenges make this would not be easy. The challenges are as techniques and packaging methods. These must be good and right so the farmer can understand the process easier because the human resource (farmer) relatively has low education. The effectiveness of using mass media to share information is influenced by the design of media itself (Cooke, L. 2005). States that it needs consideration to the product (product material selected), price (outcome cost to the program production), place (right broadcast time), and promotion (how to introduce and sell the broadcast program) in the program plan (Morissan. 2008).

Schramm (Zainal, A. G.,et al. 2019). explains the functions of mass media are as an information giver which the information will be hard to share fastly and on time without the use of mass media, as a decision-maker which mass media can be used as supporting media that operates as a decision-maker in the discussion of some groups and mass media has a role to share things that matter to be discussed, also can make the problem evident and the third as an educator.

Radio is a practical, cheap, and affordable media that all people can use. Most of the people in rural areas still use the Radio. The role of Radio in the communication process is "to inform," "to educate," and "to entertain." It relates to the study by Mulyandari, Saleh \& Dadan. Radio can facilitate information about agribusiness and agriculture development (IPTEKS) in agriculture and rural development (Mulyandari, R., et al. 2010).Radio acts as a communication media among agriculture people, becomes learning media and entertainment media related to the needs of the agriculture community, to build valuable agribusiness communities that can be a source of information for all of the people and make the agriculture development develops faster.

The farmers can get the information from mass media, both printed (bulletin or rural newspaper) and electronic (community radio or rural internet access) to fulfill information needs. Radio is one of the media that is still assumed representative to be used. It is a kind of mass media that uses to share the information invoice in the form of the broadcast program regularly and continuously. The benefits of Radio are fast, familiar, cheap, and flexible.

The Agriculture Information Center can be used as a media for some institutions that do the innovation dissemination. This innovation, both in the form of knowledge and technology, is needed by the people in rural. Therefore, there must be a synergism between the institution and the Information Center of Agriculture Development to make the information spread accurately to rural people. Based on the background of the problem above, this article's objective was to know the institutional role of the Agriculture Development Information Center in rural and to know the effort to create synergism between an involved institution with the Information Center of Agriculture Development (PIPP). 


\section{Framework of The Study}

Farmers need the information to run their agriculture business to be better by using technology and information that have been existed along these times. The information must be accessible to farmers to make them able to apply it in their agriculture business, and the farmers can qualify for trusted news. The counseling role and communicative intervention are assumed as the transfer and knowledge dissemination from research to the farmer or from "early adopters" to other farmers for a long time. According to Chambers, this thing is referred to as a model of counseling "Technology Shift" (Leeuwis, C., \& Sumarah, B. E. 2009).

The more ideas of innovation about developing resources through communication information and people's knowledge, the more innovations will be created that are involved in communication media, both printed (bulletin or rural newspaper) and electronic (community radio or rural internet access. The technology development of communication information (TIK) and the progress of Science and Technology (IPTEK) affect the improvement of knowledge and information needs used to support agriculture development. These things are becoming the background to build the Information Center of Rural Development (PIPP).

Information Center of Rural Development (PIPP) defines a communication institution that can help the other research institutions or other sources produce further information so that the information will be more transparent and understandable by the people (rural people). Besides, this institution can make the information easy to access on time. Furthermore, the information Center of Rural Development (PIPP) can also be defined as a tool s used to share data between some parts of people related to the rural development.
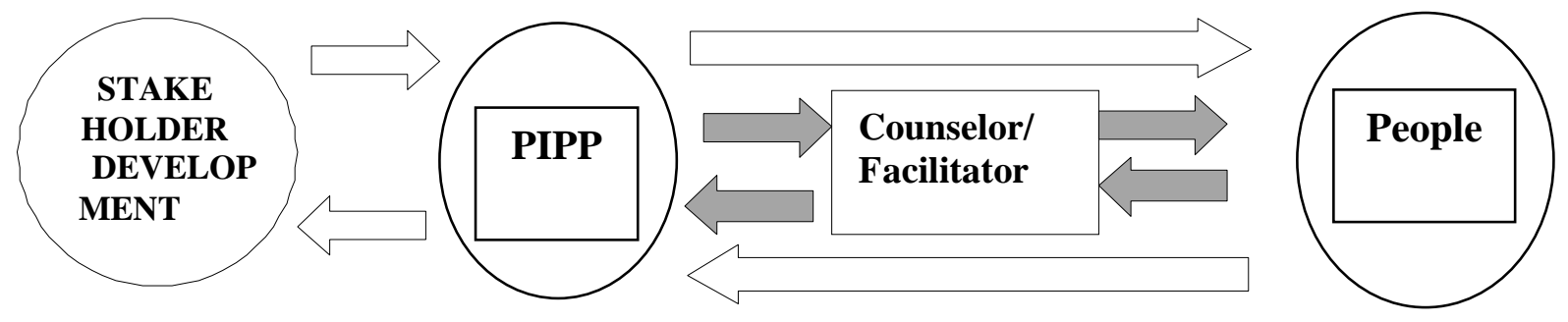

Picture 1. Relations between stakeholders with people

Information Center of Agriculture Development (PIPP) is a representative from some institutional that supporting the process of agriculture development, includes the research institution, campus, mass media, farmers discussion forum, agriculture counselor, government apparatus, and people self-subsistent institution (LSM), or can be the set of the institution itself that creates an integrated network for Information Center of Agriculture Development (PIPP). An integrated network aims to make the Information Center of Agriculture Development (PIPP) become an institution that is not only for collecting information but also can share the information with the people, so that they will know and want to do some things better, especially in case of rural development. Lionberger defines the Information Center of Agriculture Development (PIPP) as an institution of communication development which can be positioned as "among variable" that have some functions as follows (Mardikanto, T. 2009).

First, as a distribution of information/innovation: from source to the people who need the information and can use it, the extension worker has shared the feedback of information/innovation. Second, as a problem solving, that operates as facilitator and information intermediary who can solve the issues faced by people, practitioners, users, and specific product customers, to the information source/innovation/related product, and the decisionmakers. And the last is for taking a decision, as a facilitator or information intermediary about development policy from decision-maker to the people and information intermediary from people about a procedure that the outsider must decide.

According to Mardikanto, the counseling material is all of the messages that wanted to tell by a counselor to the people. This message can be informative, persuasive, and entertaining and can change or push improvements that make people better in all aspects of life. Havelock differentiates the informative message into four messages: basic knowledg, applied research findings and development, practical knowledge, and the message user. These types of the message correlate with others.

The definition of institutional involves two important demarcations, namely (1) norm and convention (norms and conventions), and (2) play rules (rules of the game). The Institutional wrote formally as it seems in the norm and custom rules the people follow (Tisenkopfs et al., 2015). Generally, the institutional can be predicted and 
stable enough and can be applied to a recurring situation. It can be defined as a set of working rules of going concerns. Therefore, the institutional defines is a collective activity under the control or jurisdiction, exemption or liberation, and the expansion of individual activity mentioned above (Arifin, B. 2005).

According to Arifin the scope of institutional can be limited on some things as follows; Institutional is a human creation which are the results from an effort or human activity that was done consciously. The second is a group of individuals that should be formulated and decided together with the group, not individually. The Third is the time dimension, in which the institution is not created for one or two moments on a specific setup time. The fourth is a place dimension, in which the institutional arrangement has an essential function on condition changing or physical environment. The fifth is rules and norms, which an institutional is decided by a configuration of rules and standards that some groups of people had formulated. Sixth is Monitoring and enforcement, in which the rules and norms must be monitored and enforced by the competent institution or by internal people on the individual level. Seventh is hierarchy and network (nested levels and institutions), a part of hierarchy and network or complex institutional system. Generally, there are two levels of consequence. First, the institution develops the routines, regularity, or human action that no need to be completed and perfect. Secondly, an institutional affects the stable creation of interaction that each individual internalizes.

There are nine essential things involve in an institution as follows (Purwaka, T. H. 2008). which is Law base of an institutional consists of a set of law regulations; A purpose that will be achieved with the rational law base; The existence of an authority, main job and institution function; Facilities and infrastructures to implement the authority, main job and institution function; Human resource that needs as an authority executor, main job and institution role; Human resource is able to decide the level of success from authority executor, main job and institution function; Mechanism or a framework from authority executor, main job and institution function as it seems on prediction and reasoning to the law base with the rational argumentation; A network among institutions that can be understood by prediction and reason on the law base with the sensible argumentation; Work result from authority, main job, and institution function as can be known by prediction and explanation on the law base with the practical argumentation;

Agriculture institutional is a structured norm and a patterned habit that is applied continuously to fulfill the farmers' needs related to their life in the agriculture field. The position and function as part of social prenatal that facilitated social interaction or social interplay in a lively community of farmers. Agriculture institutional has a strategic point (entry point) to move the agribusiness system at rural. All of the resources in the rural area need to be narrowed/prioritized to improve the professionalism and farmer bargaining position (farmer group). Nowadays, the farmer and farmer institutional in Indonesia is still not as good as expected (Nasrul, W. 2012).

A farmer institutional is the organization of people in rural-based on agriculture. This organization involves; farmer group, woman farmer, man farmer, and farmer contact (Sunanto, \& Yuniarsih, E. 2011). Creating a farmer group in rural is based on the similarity of territory, purpose, point of view, and needs - the farmer group as an institution that controlled the agriculture executor (farmer) in some commodity production sectors. The activity must be activated, collected, advised, strengthened, and empowered so that the transformation process of knowledge and technology can be easier to do. Agriculture institutional potential is characterized by leadership behavior, regulations, social norm, institutional structure, institutional role, and social tolerance among people. Therefore, the position and function of a farmer's institutional is a part of social pranata that facilitated the social interaction in a community.

Institutional functions are to build and develop the agriculture sector. In Indonesia, the tasks of an institution can be seen in the agriculture activity of planting food, especially planting rice. The institutional role of agriculture development at the national macro level very stands out in the program, intensification project, and food production improvement. Agriculture development activity is in the form of a program and project with the institutional development forced (a forced institutional), such as Rice Center, Mass Demonstration (Demas), Mass Guidance (Bimas), Bimas Communal Work, Village Institution Business Unit (BUUD), Village Cooperative Unit $(K U D)$, Census and Supra Census. The farm is developed in sub-sectors of some programs and forced institutional development, such as Bimas of purebred chicken, free-range chicken intensification (Intab), buffalo livestock intensification (Intek), also on some programs and the other institutional intensifications.

According to Dimyati (2007) There are the farmer's institutional problems that still exist that they have lack of knowledge in the production and marketing network, the farmer activity focus on on-farm not on off-farm, and the function of institutional is not optimal. 
Referring to the problems above, there must be an effort in case of development, empowerment, and to strengthen, the farmer institutional (such as farmer group, labor institution, institutional input provider, output institutional, instructor institutional, and capital institutional) and these are hoped that can protect the farmer bargaining position. The protection acts can be in the case of farmers as a producer and as a consumer that is resulting from their effort in the agriculture field which can make the price become high and their life could be better. Therefore, the strengthening and empowerment of an institution also aim to gain natural resources and some business continuously and sustainably to support the life activity of agriculture development in rural.

\section{Methods}

This study uses the interpretism or constructivism paradigm that is related to the interpretation, giving meaning to individual experiences. The method of this research used literature review by searching relevant references which is related to the research problems about types of institutions, institutional roles and efforts made. A literature study is one of the research methods where the data are taken from reference, reading, notes taking, and counting the data as the source (Melfianora. 2019). Data and information were collected through observation. The origins of this research were taken from journals, documentation books, the internet, and reference. After collecting the data, then it was analyzed by using the descriptive analysis method. The descriptive analysis method was done in the form of fact descriptions that were organized and analyzed by giving an understanding and enough explanation of the research findings.

\section{Discussion}

The information about agriculture development cannot be shared at one time to all people; sometimes, there is an information discrepancy caused by some aspects, such as the problem of long-distance. Therefore, Radio is one of the mass media that can cover up the issue of information discrepancy and long-distance. Audio media has superiority such as speed to share the information, the easiness to access radio broadcast, low cost, wide broadcast range, building a listener's imagination, personally, can be heard wherever people want in their daily lives, and able to reach signal at hinterland.

One of the efforts that push the use of technology innovation in society is to identify the availability of information about the farmer technology through survey and participative assessment (Schouten \& Glasbergen, 2011), agriculture technology that developed through the process of participative by input the local knowledge resource will make sure that the implementation can be sustainable. According the implementation of good governance policeis taken by the government must be relate to people's participation (Haitami, M., \& Rengganis, A. 2021).

\subsection{The institutional role of rural agriculture development in Indonesia}

Agriculture institutional is a farmer organization that can be widely defined as a set of play rules or behavior rules that determined the act of an institution. An agriculture institutional is created to fulfill some farmer's needs; this is how the institution works. The institutional role is one of the essential aspects that support the radio community's continuity in the case of getting agriculture information, where the involved institution can be as an interviewee to enrich the farmer knowledge.

In carrying out their roles, these institutions function as bridges for disseminating information. Along with the theory of diffusion of innovation, diffusion is the process by which innovation is communicated through certain channels over a period of time, among members of a social system (Rogers, E. M. (1995). Messages disseminated in the communication process contain ideas, or practices that are new or considered new. Diffusion is an innovation medium used by agents of change when trying to persuade someone to adopt an innovation. Some institutions involved in the radio community on PIPP are as follows:

a. The local university (Tri Dharma College) implements the activity of devotion to the people. This activity can be done as a form of cooperation due to the dissemination to the local farmers. In reality, this institution can build a partnership with farmers to have symbiosis mutualism between an institution and the farmers. The institutional role is to transfer knowledge, and farmers will get the understanding that, in the end, they can apply technology in their agriculture field. The farmer tends to get many pieces of information that can be disseminated on some variations of knowledge. It relates to the result of a study from Martina and Shamdiyah (2016) that a college has a vital role in transferring an agriculture innovation technology and graduates the beneficial bachelor who can compete and able to do actual agriculture activity in rural (Martina \& Shamdiyah, 2016).

b. Regional governments with regional agencies can give information. Working program on the instance that can be an activity that can be applied to the people same as college, the difference in college is more focused on the model. The agency, affiliated institution, and village government are the institutions from the regional government who have the same roles such as making regional rules (PERDA), do the 
empowerment by training and guidance to give an understanding or knowledge to the farmers (Darmansyah, 2014); (Oroh, 2014).

c. The Opinion Leader at rural is the ones who can give influence the action and someone's else behavior. Opinion Leader acts as a motivator to participate in the available activity. The opinion leader is one of an element that influences the communication process at rural by doing an interactive communication strategy to give understanding and people participation, the propaganda to change the attitude and behavior also the awareness of communication to build a commitment so that the opinion leader can give a contribution to the development program (Selly Oktarina \& Sarwoprasodjo, 2018).

d. Public Self-subsistence Institution $(L S M)$ is an institution created for individuals and organizations voluntarily who give a service to the public. $L S M$ can be a motivator for public development. Positive contributions as general partners by keeping the stability and security are the part of efforts that $L S M$ can do (Herdiansyah \& Randi, 2016).

e. Farmer Institutional involves:

1) The agriculture instructor is the person who has a role in developing the farmers' self-capacity by doing counseling and training. This thing aims to improve the production, income, and well-being of life. The instructor is the people who are closer to the farmers because he often does the discussion with farmers intensively related to the problems faced by farmers. (Riana et al 2015); (Haryanto et al. 2017), that an instructor gives some information that needs by farmers, beside an instructor of selfsubsistent acts as a motivator who provides motivation and gives support to the farmers to help them to solve their problems. The other actions of an instructor are to facilitate and support the information needed for farmers from the research institution and government counseling.

2) Farmer contact is a term that refers to the farmer leader group who can develop knowledge, able to lead and motivate his members. Besides, farmer contact becomes the vice of discussion or another activity.

3) Combined Farmer Group (Gapoktan) is a group of some farmers groups that do the activity based on togetherness to improve the income together.

4) A farmer group is a group of farmers that consciously creates a group with the same purpose, motive, and interest to develop and improve the member's effort. Although the member of the farmer group consists of some characters, they have different interests and abilities so that they can change ideas from one to another.

f. Other institutions, the other institutions that have not been mentioned here yet, have potential as an information center related to their region.

A communication strategy can be a message that all people can understand. PIPP as an institution needs a structured organization to run the planned program. An organization has a leader who responded fully to the organization management, under the control of a protector and advisor by coordinate some divisions that have their specifications in doing their jobs. The structure of PIPP institutional can be seen as follows:

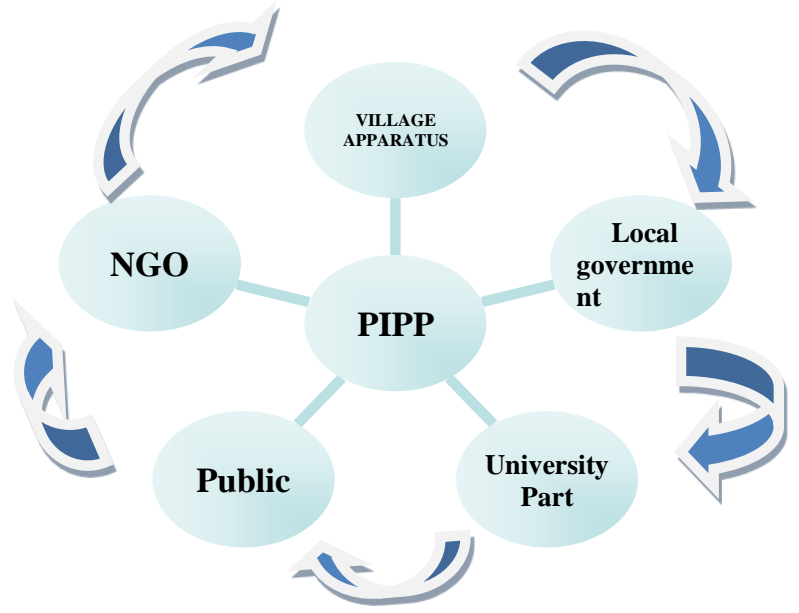

Picture 2.Institutional Structure of PIPP

4.2 Institutional Synergism of PIPP

Synergism defines as an involved activity that has a significant influence. Based on this definition, the institutional of PIPP can work together as synergism so that it can give a better result and raise a big power that can be used as an activator to do public change in rural. Otherwise, if there is no synergism in the institutions so 
that these institutions will operate by themselves. Therefore, the difference would be hard to reach, or in other words, this institutional is failed.

Institutional synergism has genuinely had a function to make perception the same, giving attention and the management to the PIPP. Based on its urgency side, the existence of PIPP is essential because the public can use it in rural. It relates to the purpose of PIPP to support the people and information source and educate and improve the well-being of life. For these reasons, the synergism is needed to be maintained continuously so that there will be harmony. The institutional function can be run well if the agriculture field has an appropriate strategy, especially in agriculture field management. It is a must for an institution to pay attention to the situation and agriculture development change by seeing the existing challenges and using an effective communication strategy to support the development effectively.

Farmer institution has a strategic point to run the agribusiness system in rural (Nyangena, 2008). For this reason, all of the resources in rural must be directed/prioritized to improve the professionalism and farmer bargaining position. However, the purpose of the agriculture development sector is still far from affirmation. Some of the problems in the agriculture field; (1) The farmers lack insight and knowledge about production management and marketing network. According to Mulyandari and Ananto (2005) in (Oktarina, 2020), that the unavailable of information about market and technology (2) farmers are not involved in the human resource activity because their activities are still focused on production activity, and (3) role and function of farmer institution as a place for the farmer organization, it exists although it does not work optimally.

Some efforts can do by an institution as follows:

a. Farmer empowerment can occur by equalizing perception, communication approach, communication process, and social interaction intensity.

1) Farmers must have the same perception of the involved institutional in the development program to make the synergism between institutional can be created and goes well.

2) The communication approach tends to do linearly, relating to the resulting research by Oktarina and Rustiadi ${ }^{i}$ showed that communication approach changing must be an interactive approach.

3) The communication process, the process of effective communication, aims to get the farmer's interest in the program so that there will be a rise of understanding and farmer participation.

4) Social interaction intensity. The intensity of effective social interaction shows that the social distance gets close and has harmonious purposes-empowerment of an institution both in farmer institutions and government institutions.

b. The empowerment of farmer institutions in the region, such as farmer groups, labor institutions, input provider institutions, information institutions, and capital institutions that are expected, can improve the farmer's bargaining position. According to the research by Andrianty and Setyorini, most of the farmers $(75 \%)$ assume that institutional communication is available to fulfill the agriculture information; the other parts $(26 \%)$ think that institutional communication is less known. BPP/field instructors are available in each district from the regency that had been surveyed, complete with the office staff, so that these can make it easy to interact or communicate with $B P P /$ instructor to get the information. It is supported by the farmers' excellent perception (90\%) towards the meeting with a formal instructor (by the government). Through this meeting, farmers can get information related to production technology, result-producing, and marketing.

Another function of strengthening and empowering these institutions is to continuously and sustain and support the agriculture development activity. Therefore, the Information Center of Rural Development (PIPP) is needed to strengthen the farmer and is expected can give a solution to the farmer's problems.

c. Regulation of institutional capacity through management repairing, making rules, leadership patterns, and transparency.

1) Institutional repairing management can be done by making institutional structures, improving the leadership pattern, and having transparency. There is an example of a farmer's institutional system of cane farmer where there are no main rules to manage the job and relation among members to run the function of the organization or institution.

2) It was making play rules that know the duty based on the primary responsibilities and functions. The case often exists a farmer group with no written rules to manage the authority and norm, which has relations among members. Along these times, it is running based on the discussion among members. Even though an institutional or organization needs to work on some management functions, namely planning, organizing, actuating, dan controlling (POAC).

3) The institutional deal aims to manage and find a way to create good relations among units, collaboration, and competition. The institutional agreement has a relation with institutional governance, agriculture institutions. The communication institution aims to fulfill the agriculture information as formal and non-formal, social institutions, also social/religion is institutional. These institutional are 
available on the location of research. But, the legal status of an institution is different in each area. The counseling activity in each place can be controlled by an institution separated from a specialized agency, even though the name is other. In some homes or regencies, the counseling activity is still merged with the Agriculture Agency of Food Plant and Farm. The differences of regency government policy in the counseling activity presumed will decide the intensity of counseling activity will affect the farmer's perception of the availability or existence of counseling institutional.

4) Leadership pattern must do a paradigm change on the institutional of cane farmer, the model of change from top-down character to the bottom up to build the communication pattern and aspiration in the institutional. The bottom-up model will decrease the farmer domination developer and maximize some social models available in a rural place that becomes a farmer's basis.

5) Transparency is a determination of communication technology and information online. This thing aims to develop the institutional transparency management that along these times it works manually, or the computer is not working as an online network yet that it must be customized with the globalization era. The management of farmer institutional can create the Information Center of Rural Agriculture (PIPP) based on the internet, making it easier for the farmer to access the information about farmer institutional. The management of farmer institutional will be more transparent because it is under the control of members and the public.

Referring to the explanation about institutional synergism above, it also relates to Damanik and Tahitu's (2020) research that institutional synergism needs to exist in the farmer empowerment strategy to search the information. The dynamic institutional are farmer group synergism, farmer counselor, college, local research institution, regional government, and internet service.

\section{Conclusion}

The empowerment of institutional role based on the Information Center of Rural Agriculture $(P I P P)$ in Indonesia could improve the accessibility of information done by farmers to the institutional. Therefore, institutional empowerment will push the improvement of farmer productivity, affecting the well-being of farmer life. Besides, there must be a synergism among farmer institutions so that the planned programs created by agriculture institutions can run well. Therefore, there must be supporting empowerment from government, private, and instance related to improving farmer institutional performance.

\section{ACKNOWLEDGEMENT}

This manuscript would not have been possible be completed without generous support of our mentor, Dr. Ir. Amiruddin Saleh, M.Si, Dr. Cahyono Tri Wibowo, S.E, MM and support from Rural Development Communication Study Program, IPB University.

\section{Reference}

Alif, M. (2017). Partisipasi petani dalam komunikasi penyuluhan,. Metacommunication; Journal of Communication Studies, 2(2). https://doi.org/10.20527/mc.v2i2.4416.

Anderies, J. M., \& Janssen, M. A. (2013). Robustness of social-ecological systems: Implications for public policy. Policy Studies Journal. https://doi.org/10.1111/psj.12027

Andriaty, E., Sankarto, B., \& Setyorini, E. (2011). Kajian kebutuhan informasi teknologi pertanian di beberapa Kabupaten di Jawa. Perpus. Pertanian, 20(2).

Arifin, B. (2005). Ekonomi Kelembagaan Pangan. LP3ES.

Cooke, L. (2005). A visual convergence of print, television, and the internet: Charting 40 years of design change in news presentation. In New Media and Society. https://doi.org/10.1177/1461444805049141

Haitami, M., \& Rengganis, A. (2021). The Dilemma of Good Governance Implementation in Indonesia during the Pandemic of Corona Virus Disease (COVID-19). Journal of Advance in Social Sciences and Policy, 1(1), 55-67. https://doi.org/10.23960/jassp.v1i1.25

Leeuwis, C., \& Sumarah, B. E. (2009). Komunikasi untuk inovasi pedesaan: berpikir kembali tentang penyuluhan pertanian. kanisius.

Lorayna, K. J. A., \& Caelian, M. V. (2020). Civil Society Organization Participation in Comprehensive Agrarian Reform Program Implementation. Philippine Social Science Journal Civil, 3(1), 127-141.

Mardikanto, T. (2009). Sistem Penyuluhan Pertanian. Surakarta. Universitas Sebelah Maret Press.

Melfianora. (2019). Penulisan Karya Tulis Ilmiah dengan Studi Literatur. Open Science Framework.

Morissan. (2008). Manajemen Media Penyiaran: Strategi Mengelola Radio \& Televisi. Manajemen Media Penyiaran: Strategi Mengelola Radio \& Televisi.

Mulyandari, R., Saleh, A., \& Dadan. (2010). Revitalisasi Radio Pertanian Ciawi (RPC) sebagai Pusat Informasi Pembangunan Pertanian. Informatika Pertanian, 19(1). 
Muñoz-Pascual, L., \& Galende, J. (2020). Ambidextrous knowledge and learning capability: The magic potion for employee creativity and sustainable innovation performance. Sustainability (Switzerland). https://doi.org/10.3390/SU12103966

Nasrul, W. (2012). Pengembangan Kelembagaan Pertanian Untuk Peningkatan Kapasitas Petani Terhadap Pembangunan Pertanian. Menara Ilmu.

Oktarina, S., \& Rustiadi. (2008). Keefektivan Komunikasi dalam Pengembangan Peran-Peran Kelembagaan Agropolitan. Jurnal Komunikasi Pembangunan. https://doi.org/10.29244/jurnalkmp.6.2.\%p

Oktarina, Selly, \& Sarwoprasodjo, S. (2018). Strategi Komunikasi Politik Opinion Leader Dalam Difusi Program Pembangunan Dan Pengembangan Lembaga Lokal Di Pedesaan (Opinion Leader Political .... Metacommunication: Journal of ..., 3(1). https://doi.org/http://dx.doi.org/10.20527/mc.v3i1.4687

Purwaka, T. H. (2008). Model Analisis Pengembangan Kapasitas. Penerbit Fakultas Hukum Unika Atma Jaya.

Quingco Joyfe G, \& S, L. C. (2019). The Economic Impact, Contribution, and Challenges of Micro Business Enterprises to the Local Development. Philippine Social Science Journal The, 2(2), 107-122.

Rogers, E. M. (1995). Diffusion of inovation (Fifth Edit). Free Press.

Sunanto, \& Yuniarsih, E. (2011). Gapoktan Menyambut Program Subsidi Pupuk Langsung ke Petani. Buletin Inovasi Dan Informasi Pertanian BPPT http://sulsel.litbang.deptan.go.id/ind/index.php?option=com_content\&view=

Tisenkopfs, T., Kunda, I., šūmane, S., Brunori, G., Klerkx, L., \& Moschitz, H. (2015). Learning and Innovation in Agriculture and Rural Development: The Use of the Concepts of Boundary Work and Boundary Objects. Journal of Agricultural Education and Extension. https://doi.org/10.1080/1389224X.2014.991115

Touihri, M., Séguy, M., Imbeau, L., Mazerolle, M. J., \& Bird, D. M. (2019). Effects of agricultural lands on habitat selection and breeding success of American kestrels in a boreal context. Agriculture, Ecosystems and Environment. https://doi.org/10.1016/j.agee.2018.11.017

Zainal, A. G., Singagerda, F. S., Sanusi, A., \& Akbar, M. F. (2019). Community development communication model and improving the role of agropolitan institutions. International Journal of Scientific and Technology Research.

Zainal, A. U., \& Prakoso, G. H. (2019). The Influence of Emotional Intelligence and Motivation Toward Agricultural Extension's Performance at Agricultural Office of Tanggamus District. Jurnal Penyuluhan, 15(1). https://doi.org/10.25015/penyuluhan.v15i1.17081 